\title{
Dissolved N:P ratio changes in the eastern tropical North Atlantic: effect on phytoplankton growth and community structure
}

\author{
Jasmin M. S. Czerny ${ }^{1}$, Helena Hauss ${ }^{1}$, Carolin R. Löscher ${ }^{2}$, Ulf Riebesell ${ }^{1, *}$ \\ ${ }^{1}$ GEOMAR Helmholtz Centre for Ocean Research Kiel, Düsternbrooker Weg 20, 24105 Kiel, Germany \\ ${ }^{2}$ Institut für Allgemeine Mikrobiologie, Christian-Albrechts-Universität zu Kiel, Am Botanischen Garten 1-9, 24118 Kiel, Germany
}

\begin{abstract}
Previous bioassays conducted in the oligotrophic Atlantic Ocean identified availability of inorganic nitrogen $(\mathrm{N})$ as the proximate limiting nutrient control of primary production, but additionally displayed a synergistic growth effect of combined $\mathrm{N}$ and phosphorus (P) addition. To classify conditions of nutrient limitation of coastal phytoplankton in the tropical ocean, we performed an $11 \mathrm{~d}$ nutrient-enrichment experiment with a natural phytoplankton community from shelf waters off northwest Africa in shipboard mesocosms. We used pigment and gene fingerprinting in combination with flow cytometry for classification and quantification of the taxon-specific photoautotrophic response to differences in nutrient supply. The developing primary bloom was dominated by diatoms and was significantly higher in the treatments receiving initial $\mathrm{N}$ addition. The combined supply of $\mathrm{N}$ and $\mathrm{P}$ did not induce a further increase in phytoplankton abundance compared to high $\mathrm{N}$ addition alone. A secondary bloom during the course of the experiment again displayed higher primary producer standing stock in the $\mathrm{N}$-fertilized treatments. Bacterial abundance correlated positively with phytoplankton biomass. Dominance of the photoautotrophic assemblage by N-limited diatoms in conjunction with a probable absence of any P-limited phytoplankton species prevented an additive effect of combined $\mathrm{N}$ and $\mathrm{P}$ addition on total phytoplankton biomass. Furthermore, after nutrient exhaustion, dinitrogen $\left(\mathrm{N}_{2}\right)$-fixing cyanobacteria succeeded the bloom-forming diatoms. Shelf waters in the tropical eastern Atlantic may thus support growth of diazotrophic cyanobacteria such as Trichodesmium sp. subsequent to upwelling pulses.
\end{abstract}

KEY WORDS: Phytoplankton - Nutrient limitation - Nitrogen and phosphorus stoichiometry · Diatoms $\cdot$ Diazotrophic cyanobacteria $\cdot$ Trichodesmium $\cdot$ Upwelling

\section{INTRODUCTION}

Various concepts have been proposed about the nature of nutrient limitation acting on the phytoplankton community of the pelagic tropical Atlantic. Short-term bioassays in the eastern Atlantic that included additions of inorganic nitrogen $(\mathrm{N})$, phosphorus (P) and dissolved iron (Fe) determined $\mathrm{N}$ as the key limiting nutrient for total primary production (e.g. Graziano et al. 1996, Mills et al. 2004, Moore et al. 2008). Some of these experiments, however, also

${ }^{*}$ Corresponding author: uriebesell@geomar.de indicated an apparent co-limitation of $\mathrm{N}$ and $\mathrm{P}$ (Moore et al. 2008), or Fe and P (Mills et al. 2004), but on a more taxon-specific level. In particular, Fe and surplus $\mathrm{P}$ are assumed to provide a niche for diazotrophic phytoplankton (Mills et al. 2004). The gradient in subsurface nutrient N:P ranges from Redfield proportions ( 16:1) in the eastern Atlantic to relatively high values (>30:1) in the western Atlantic, which implies a transition from slight $\mathrm{N}$ to severe $\mathrm{P}$ limitation (Fanning 1992, Wu et al. 2000, Moore et al. 2008).

(C) The authors and GEOMAR 2016. Open Access under Creative Commons by Attribution Licence. Use, distribution and reproduction are unrestricted. Authors and original publication must be credited.

Publisher: Inter-Research · www.int-res.com 
In view of the apparent absence of significant pelagic $\mathrm{N}$ loss in the eastern tropical North Atlantic (ETNA) (Ryabenko et al. 2011), the lower N:P signature in this area appears to be conflicting with the high supply of $\mathrm{N}$ via $\mathrm{N}_{2}$ fixation (e.g. Falcón et al. 2005, Voss et al. 2004), riverine discharge (N:P 22; Nixon et al. 1996) and dust deposition (N:P 19; Talbot et al. 1986). Generally, oxygen $\left(\mathrm{O}_{2}\right)$ in the underlying oxygen minimum zone (OMZ) of the ETNA exceeds threshold concentrations that would enable large-scale water column denitrification, with mean concentrations of 40 to $50 \mu \mathrm{mol} \mathrm{kg}{ }^{-1}$ (Karstensen et al. 2008), compared to the severely $\mathrm{O}_{2}$-deficient waters in the eastern tropical Pacific and the Arabian Sea. Nevertheless, severe $\mathrm{O}_{2}$ depletion has recently been detected in the core of spin-off eddies at the Cape Verde Ocean Observatory in the ETNA (Karstensen et al. 2015). Moreover, recent studies indicate benthic $\mathrm{N}$ loss via denitrification and anaerobic ammonium oxidation (anammox) within the sediment of the northwest African continental shelf (Trimmer \& Nicholls 2009, Jaeschke et al. 2010). With further deoxygenation of tropical OMZs (Stramma et al. 2008), intermediate waters with reduced N:P stoichiometry will increasingly be transported via coastal upwelling into the euphotic zone, forcing primary production towards $\mathrm{N}$ limitation. Along with high Fe supply by dust deposition from the African continent (Gao et al. 2001), low N:P conditions generally favour growth of diazotrophic over non-diazotrophic phytoplankton. As a result, cyanobacteria such as the filamentous Trichodesmium (Capone et al. 1997, Tyrrell et al. 2003) and several groups of unicellular diazotrophs (e.g. UNCY-A, UNCY-B, UNCY-C cyanobacteria, diatom symbionts and various clades of Proteobacteria; see e.g. Falcón et al. 2002, Langlois et al. 2008) are highly abundant throughout the tropical and subtropical Atlantic and contribute significantly to the input of new $\mathrm{N}$ via biological $\mathrm{N}_{2}$ fixation (Großkopf et al. 2012).

In the realm of the northwest African upwelling, phytoplankton communities are primarily dominated by representatives typical of eutrophic systems, such as diatoms, the haptophyte Phaeocystis and dinoflagellates (Margalef 1978). Growth of diatoms and dinoflagellates is controlled by $\mathrm{N}$ availability (Ryther \& Dunstan 1971, Hauss et al. 2012), while P. globosa has been reported to favour low N:P supply ratios (Riegman et al. 1992, Hauss et al. 2012). However, based on their low cellular N:P stoichiometry (Quigg et al. 2003, Arrigo 2005), diatoms are suspected to exploit a considerable fraction of freshly upwelled $\mathrm{P}$ on the shelf by non-Redfield production, possibly reducing the availability of $\mathrm{P}$ for phytoplankton groups, in particular diazotrophs, following later in the succession as the upwelled water is transported offshore (Mills \& Arrigo 2010, Franz et al. 2012a).

In a complementary publication on this mesocosm experiment, production of organic matter in response to different nutrient supply conditions indicated an overall $\mathrm{N}$ limitation of total primary production (Franz et al. 2012b). The focus of this study is to elucidate the taxon- to species-specific response by the photoautotrophic community to a gradient in nutrient stoichiometry. Key questions in this context are to what extent changes in the $\mathrm{N}$ :P supply ratio are buffered by non-Redfield production, what phytoplankton groups are responsible for this, and whether excess $\mathrm{P}$ is a prerequisite for the proliferation of diazotrophic cyanobacteria in the successional pattern following upwelling of nutrient-rich waters.

\section{MATERIALS AND METHODS}

\section{Mesocosm experimental set-up}

A nutrient limitation experiment in shipboard mesocosms was conducted using a natural phytoplankton community during RV 'Meteor' cruise M831 from Las Palmas (Gran Canaria, Canary Islands) to Mindelo (São Vicente, Cape Verde) in October and November 2010.

Twelve mesocosms in 4 flow-through gimbalmounted water baths on deck (see Fig. 2 in Franz et al. 2012b) were each filled with 1501 of natural seawater from about $5 \mathrm{~m}$ water depth $\left(15^{\circ} 0.01^{\prime} \mathrm{N}\right.$, $17^{\circ} 45.00^{\prime} \mathrm{W}_{\text {; ca. }} 35 \mathrm{~km}$ northwest of Dakar) using a peristaltic pump. The medium was not pre-screened for mesozooplankton, as abundance was low at the filling sites. Single copepods spotted on the GF/F filters during filtration for particulate organic matter were removed by hand.

The individual mesocosm enclosure was a cylindrical plastic bag with a plexiglass bottom fixed to a floating tire. Continuous flow of ambient surface seawater through the water baths via in- and outflow provided in situ temperature conditions $\left(<2{ }^{\circ} \mathrm{C}\right.$ above sea surface temperature).

Surface irradiance in the mesocosms was reduced by $60 \%$ to $100-600 \mu \mathrm{mol}$ photons $\mathrm{m}^{-2} \mathrm{~s}^{-1}$ by covering the water baths with solid white lids. Initially, inorganic nutrient concentrations, viz. ammonium $\left(\mathrm{NH}_{4}{ }^{+}\right)$, nitrite $\left(\mathrm{NO}_{2}^{-}\right)$, nitrate $\left(\mathrm{NO}_{3}{ }^{-}\right)$, phosphate $\left(\mathrm{PO}_{4}{ }^{3-}\right)$ and silicate $\left.\left(\mathrm{Si}(\mathrm{OH})_{4}\right)\right)$, of the natural seawater medium were measured, and 4 different N:P 
treatments (in triplicates) were adjusted by nutrient additions $\left(\mathrm{NaNO}_{3}\right.$ and $\left.\mathrm{KH}_{2} \mathrm{PO}_{4}\right)$. Treatment replicates were distributed over the different water baths. Initial molar N:P supply ratios ranged between 16:1 and 2.8:1 (Table 1). To prevent limitation of essential nutrients other than by $\mathrm{N}$ or $\mathrm{P}, 15 \mu \mathrm{mol} \mathrm{l}^{-1}$ $\mathrm{Na}_{2} \mathrm{SiO}_{3} \cdot 5 \mathrm{H}_{2} \mathrm{O}$ and $10 \mathrm{ml}$ of a trace metal mix (Provasoli II trace metal mix; West \& McBride 1999) were added to all treatments. Sampling for biogeochemical and taxonomical analyses was conducted on a daily basis for a period of $11 \mathrm{~d}$. Mesocosms were mixed thoroughly with a stirrer before each sampling. Technical issues during filling of mesocosm 8 (5.5:1 treatment) resulted in its exclusion from the experiment. The N:P treatment 5.5:1 was therefore only represented by duplicate mesocosms.

\section{Inorganic nutrients}

Water samples for inorganic nutrients were prefiltered through $5 \mu \mathrm{m}$ cellulose acetate filters $(26 \mathrm{~mm})$ and measured immediately after sampling using a Quaatro autoanalyzer (Seal Analytical) and an external fluorometer (Jasco FP-2020). Analysis of $\mathrm{NO}_{3}{ }^{-}$, $\mathrm{NO}_{2}{ }^{-}, \mathrm{PO}_{4}{ }^{3-}$ and $\mathrm{Si}(\mathrm{OH})_{4}$ was performed in accordance with Hansen \& Koroleff (1999), and $\mathrm{NH}_{4}{ }^{+}$was analysed according to the method of Holmes et al. (1999).

\section{Flow cytometry (FCM)}

Cell counts for phytoplankton and bacterial abundance were obtained using a flow cytometer (FACScalibur, Becton Dickinson). Samples (5 ml) were fixed with $2 \%$ formaldehyde and frozen at $-80^{\circ} \mathrm{C}$. Samples were filtered through a $64 \mu \mathrm{m}$ syringe filter prior to measurement at a flow rate of $50.6 \mu \mathrm{min}^{-1}$. Cells were distinguished by size (front scatter) and fluorescence of chlorophyll (chl) $a$, phycoerythrin and allophycocyanin. Biovolume was estimated assuming spherical shapes from a front scatter to size calibration and converted to biomass ( $\mu$ mol $\mathrm{C}^{-1}$ ) using the carbon to volume relationships described by MendenDeuer \& Lessard (2000). Because the calibration is only valid for cells $>3 \mu \mathrm{m}$, we assumed 50 and $200 \mathrm{fg}$ C cell ${ }^{-1}$ for Prochlorococcus and Synechococcus-like cells, respectively (Bertilsson et al. 2003). For bacterial abundance, samples were diluted 1:3, stained with SYBR Green and counted at a lower flow rate $(13.9 \mu \mathrm{l}$ $\min ^{-1}$ ). Unfortunately, 38 samples for bacterial abundance were lost due to inappropriate dilution.

\section{Biogenic silica}

Particulate biogenic silica (BSi) was collected by filtration of water samples onto filters made of cellulose acetate $(0.65 \mu \mathrm{m}$ pore size; $25 \mathrm{~mm}$ diameter $)$ at low vacuum pressure $(<200$ mbar) and stored frozen at $-20^{\circ} \mathrm{C}$. For analysis, each filter was incubated with $25 \mathrm{ml} \mathrm{NaOH}(0.1 \mathrm{M})$ in Nalgene bottles at $85^{\circ} \mathrm{C}$ for $2 \mathrm{~h} 15 \mathrm{~min}$ in a shaking water bath. After cooling of the incubated samples, analysis was conducted according to the method for determination of $\mathrm{Si}(\mathrm{OH})_{4}$ by Hansen \& Koroleff (1999).

\section{Phytoplankton pigments}

Samples for phytoplankton pigment analysis via high pressure liquid chromatography (HPLC) were filtered onto Whatman GF/F filters $(0.7 \mu \mathrm{m}$ pore size; $25 \mathrm{~mm}$ diameter) at low vacuum pressure and immediately stored frozen at $-80^{\circ} \mathrm{C}$. For pigment extraction, each filter was covered with approximately $3 \mathrm{~g}$ of glass beads ( $2 \mathrm{~mm}+4 \mathrm{~mm}$ mixing ratio 1:1) and $2 \mathrm{ml}$ of acetone. After homogenisation in a cell mill (Edmund Bühler) for $5 \mathrm{~min}$ and centrifugation for $10 \mathrm{~min}$ at $4779.45 \times g$, the supernatant was filtered through a $0.2 \mu \mathrm{m}$ Teflon filter and the extract stored at $-80^{\circ} \mathrm{C}$. The HPLC measurement was conducted using a Waters 600 controller in combination with a Waters 996 photodiode array detector and a Waters 717 plus auto sampler. The applied method was modified after Barlow et al. (1997). Classification and quantification of the phytoplankton pigments involving chlorophylls, carotenoids and degradation products was carried out using the software EMPOWERS (Waters).

Table 1. Overview of initial and experimental conditions during the M83-1 cruise at the mesocosm filling site. DIN (DIP): dissolved inorganic nitrogen (phosphorus)

\begin{tabular}{|c|c|c|c|c|}
\hline \multicolumn{5}{|l|}{ Initial conditions } \\
\hline Latitude & \multicolumn{4}{|c|}{$15^{\circ} 0.01^{\prime} \mathrm{N}$} \\
\hline Longitude & \multicolumn{4}{|c|}{$17^{\circ} 45.00^{\prime} \mathrm{W}$} \\
\hline Temperature $\left({ }^{\circ} \mathrm{C}\right)$ & \multicolumn{4}{|c|}{27.6} \\
\hline $\mathrm{DIN}\left(\mu \mathrm{mol} \mathrm{l} \mathrm{l}^{-1}\right)$ & \multicolumn{4}{|c|}{0.3} \\
\hline DIP $\left(\mu \mathrm{mol} \mathrm{l} 1^{-1}\right)$ & \multicolumn{4}{|c|}{0.1} \\
\hline $\mathrm{Si}(\mathrm{OH})_{4}\left(\mu \mathrm{mol} \mathrm{l}{ }^{-1}\right)$ & \multicolumn{4}{|c|}{1.4} \\
\hline \multicolumn{5}{|l|}{ Experimental conditions } \\
\hline N supply level & High $N$ & High $\mathrm{N}$ & Low $\mathrm{N}$ & Low $\mathrm{N}$ \\
\hline $\mathrm{N}: \mathrm{P}$ & 16 & 8 & 5.5 & 2.8 \\
\hline DIN supply ( $\mu$ mol l $\left.{ }^{-1}\right)$ & 12 & 12 & 4.13 & 4.13 \\
\hline DIP supply $\left(\mu \mathrm{mol} \mathrm{l}{ }^{-1}\right)$ & 0.75 & 1.5 & 0.75 & 1.5 \\
\hline $\mathrm{Si}(\mathrm{OH})_{4}$ supply $\left(\mu \mathrm{mol} \mathrm{l}^{-1}\right)$ & 15 & 15 & 15 & 15 \\
\hline
\end{tabular}




\section{nifH gene detection and quantification}

Samples for DNA purification were taken by filtering 11 seawater through $0.2 \mu \mathrm{m}$ polyethersulphone membrane filters (Millipore). The filters were immediately frozen and stored at $-80^{\circ} \mathrm{C}$. Nucleic acids were extracted using the Qiagen DNA/RNA AllPrep Kit according to the manufacturer's protocol. NifH was amplified by PCR with primers as described by Zani et al. (2000) followed by Topo TA cloning (Invitrogen) and Sanger sequencing (carried out by the Institute of Clinical Molecular Biology, Kiel, Germany). Detected nifH clusters were quantified by quantitative Real Time PCRs as previously described by Langlois et al. (2008) and Foster et al. (2007). TaqMan® qPCRs were set up in $25 \mu \mathrm{l}$ reactions containing $12.5 \mu \mathrm{l}$ TaqMan ${ }^{\circledR}$ buffer (Applied Biosystems), $1 \mu \mathrm{l}$ blood serum albumin, $0.5 \mu \mathrm{mol} \mathrm{l}^{-1}$ of the forward and reverse primers, $0.25 \mu \mathrm{mol} \mathrm{l^{-1 }}$ TaqMan probe and $5 \mu \mathrm{l}$ of template DNA or plasmid standard, respectively. Reactions were performed in technical duplicates in an ABI 7300 qPCR system (Applied Biosystems). For each primer and probe set, standard curves were obtained from dilution series ranging from $10^{7}$ to 1 gene copy per reaction; standards were constructed using environmental clones containing the target nifH gene.

\section{Statistical analysis}

As the majority of the data did not fulfil assumptions of normality and homogeneity of variances, a non-parametric Friedman test was applied to compare the significance of dissolved inorganic N (DIN) and dissolved inorganic P (DIP) supply on the development of phytoplankton pigments, $\mathrm{BSi}$, total phytoplankton biomass and Trichodesmium-specific nifH gene copy numbers. Since some data points for bacterial abundance were missing due to complications during measurement, a Durbin-Skillings-Mack test was applied. Results were considered significant at $\mathrm{p}<0.05$ for both tests.

\section{RESULTS}

\section{Nutrient drawdown}

Drawdown of the macronutrients DIN, DIP and $\mathrm{Si}(\mathrm{OH})_{4}$ set in immediately after initiation of the experiment (Fig. 1). DIN was already exhausted in all treatments by Day 3 (Fig. 1A). DIP in the 2.8:1 meso-
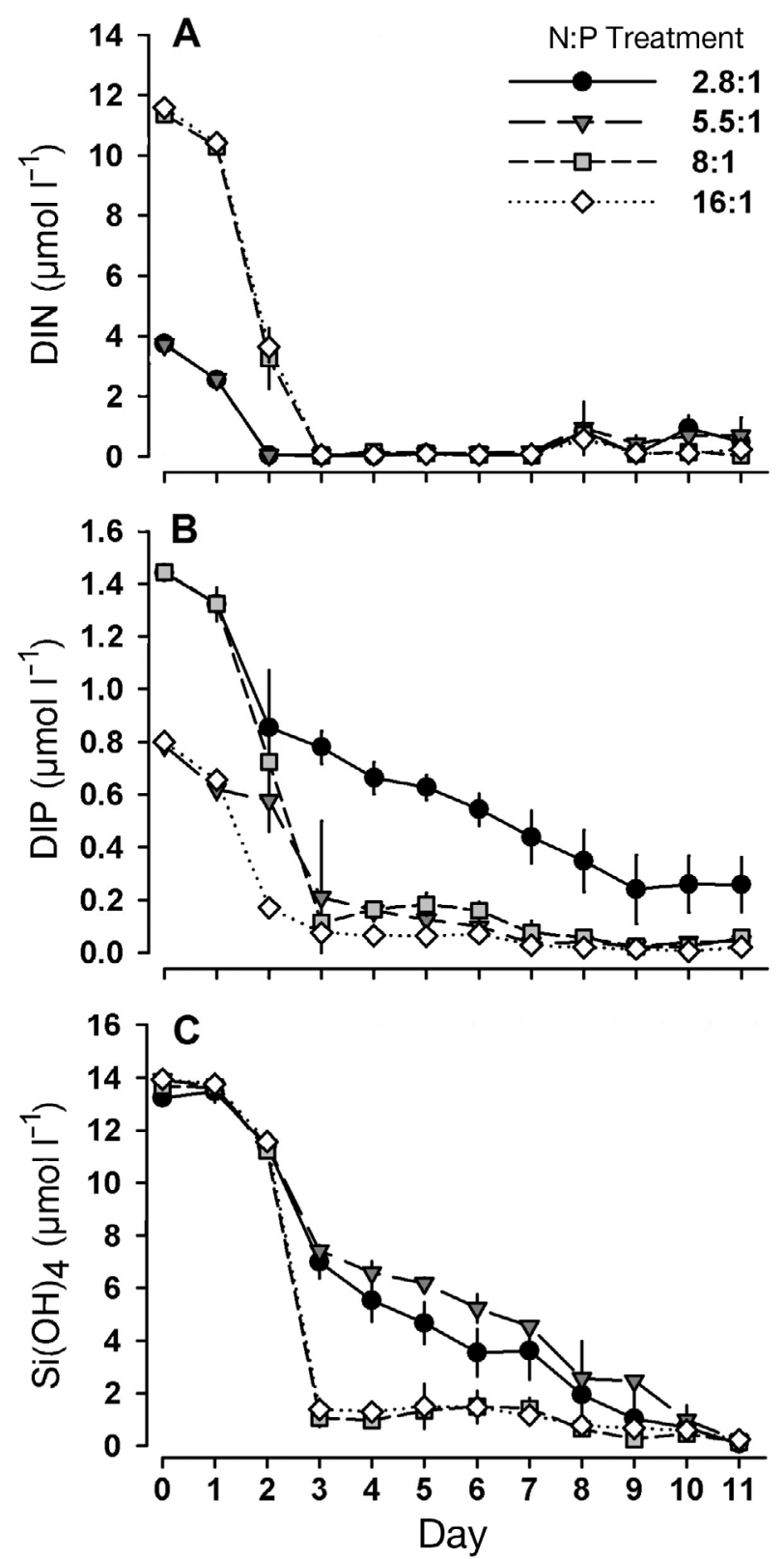

Fig. 1. Temporal development of (A) dissolved inorganic nitrogen (DIN, including $\mathrm{NH}_{4}{ }^{+}, \mathrm{NO}_{2}^{-}$and $\mathrm{NO}_{3}{ }^{-}$), (B) dissolved inorganic phosphorus (DIP) and (C) $\mathrm{Si}(\mathrm{OH})_{4}$ within the $4 \mathrm{~N}: \mathrm{P}$ treatments (see 'Materials and methods' for treatment details). Values are treatment means and vertical error bars denote the standard error of replicates within each N:P treatment

cosms decreased slowly but continuously throughout the experiment, with residual concentrations of around $0.3 \mu \mathrm{mol} \mathrm{l}^{-1}$ on Day 9. DIP drawdown was fast in the other $3 \mathrm{~N}: \mathrm{P}$ treatments. Low concentrations of $\sim 0.2 \mu \mathrm{mol} \mathrm{l}^{-1}$ were already reached on Day 3 (Fig. 1B).

Substantial consumption of $\sim 11 \mu \mathrm{mol} \mathrm{Si}(\mathrm{OH})_{4} \mathrm{l}^{-1}$ occurred in the high- $\mathrm{N}$ treatments (treatments 16:1

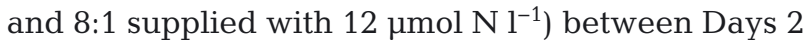


and 3 (Fig. 1C). During the same period, low-N treated phytoplankton (treatments 5.5:1 and 2.8:1

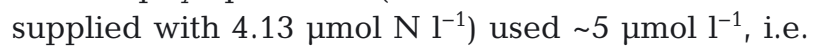
less than $50 \%$ of the available $\mathrm{Si}(\mathrm{OH})_{4}$.

\section{Biomass of phyto- and bacterioplankton via flow cytometry (FCM)}

Total phytoplankton biomass quantified via FCM was significantly affected by $\mathrm{N}$ supply (Fig. 2A, Table 2). During the primary bloom (Days 2-4), maximum biomass concentration was 4 -fold higher in high (150-200 $\left.\mu \mathrm{mol} \mathrm{C}^{-1}\right)$ compared to low $(\sim 50 \mu \mathrm{mol}$ $\mathrm{C}^{-1}$ ) N supply treatments.

Bacterial abundance was also affected by initial $\mathrm{N}$ supply (Table 2), even though the effect was less pronounced compared to the phytoplankton biomass (Fig. 2B). Approximately $20 \times 10^{6}$ cells ml $^{-1}$ accumulated until Day 6 in the high-N treatments, while cell

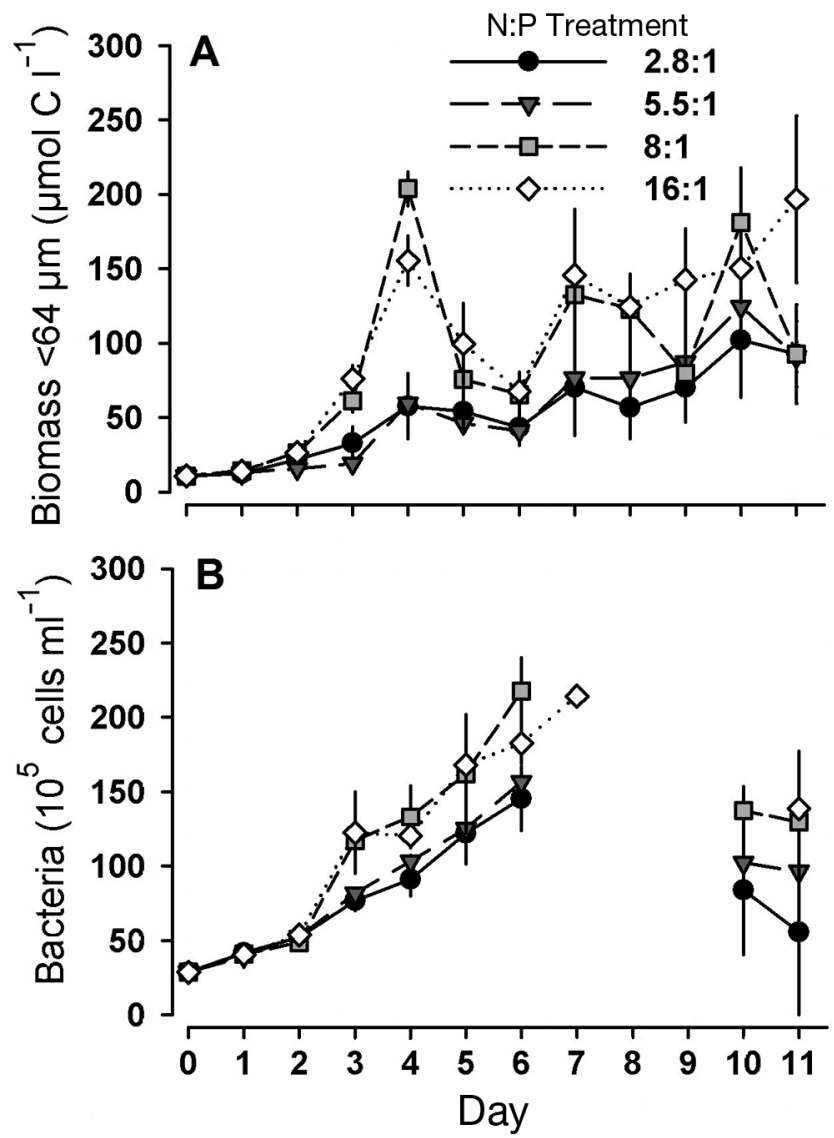

Fig. 2. Temporal development of (A) biomass of phytoplankton $(<64 \mu \mathrm{m})$ and (B) bacterial abundance derived from flow cytometry within the $4 \mathrm{~N}$ :P treatments (see 'Materials and methods' for treatment details). Values are treatment means and vertical error bars denote the standard error of replicates within each N:P treatment
Table 2. Summary of p-values of a non-parametric Friedman test comparing the significance of dissolved inorganic nitrogen (DIN) and dissolved inorganic phosphorus (DIP) supply on the development of phytoplankton pigments, biogenic silica (BSi), particulate organic carbon (POC), phytoplankton biomass $<64 \mu \mathrm{m}$, Trichodesmium-specific nifH gene copy numbers and bacterial abundance, from Days 1 to 11 .

Significant effects $(p<0.05)$ are highlighted in bold

\begin{tabular}{|lcc|}
\hline & DIN supply & DIP supply \\
\hline Phytoplankton biomass & $\mathbf{0 . 0 0 1}$ & 0.366 \\
Chl a & $\mathbf{0 . 0 0 1}$ & $\mathbf{0 . 0 3 5}$ \\
POC & $\mathbf{0 . 0 0 7}$ & 0.763 \\
BSi & $\mathbf{0 . 0 3 5}$ & 0.763 \\
Fucoxanthin & $\mathbf{0 . 0 0 1}$ & 0.366 \\
Chl c $1+2$ & $\mathbf{0 . 0 0 1}$ & 0.132 \\
Diadinoxanthin & $\mathbf{0 . 0 0 7}$ & $\mathbf{0 . 0 3 5}$ \\
Diatoxanthin & $\mathbf{0 . 0 0 7}$ & 0.366 \\
B-carotene & $\mathbf{0 . 0 0 1}$ & $\mathbf{0 . 0 3 5}$ \\
Zeaxanthin & $\mathbf{0 . 0 0 1}$ & $\mathbf{0 . 0 0 7}$ \\
Chl $c_{3}$ & 0.132 & 0.132 \\
19'-hexanoyloxyfucoxanthin & $\mathbf{0 . 0 3 5}$ & 0.763 \\
Peridinin & $\mathbf{0 . 0 3 5}$ & 0.366 \\
Aphanizophyll & 0.060 & 0.706 \\
Myxoxanthophyll & $\mathbf{0 . 0 0 2}$ & 0.527 \\
Alloxanthin & 0.070 & 0.228 \\
Chl b & 0.103 & 1 \\
Violaxanthin & 0.739 & 0.096 \\
19'-butanoyloxyfucoxanthin & 0.059 & 0.706 \\
Trichodesmium nifH genes & 0.058 & 0.206 \\
Bacterial abundance & \\
a & 0.046 & 1 \\
aurbin-Skillings-Mack test allowing for incomplete \\
data sets was used for bacterial abundance \\
\hline \multicolumn{2}{|c}{} \\
\hline
\end{tabular}

numbers reached $15 \times 10^{6}$ cells $\mathrm{ml}^{-1}$ in the low-N treatments. Data points between Days 7 and 9 are missing due to technical complications during measurement.

\section{Particulate organic carbon (POC) and proxies for taxonomical phytoplankton composition}

The temporal development of chl $a$, a proxy for total photoautotrophic biomass, was significantly affected by $\mathrm{N}$ supply (Fig. 3A, Table 2), which is in agreement with phytoplankton abundance determined via FCM. Chl $a$ in the high-N treatments exceeded those in the low- $\mathrm{N}$ treatments, in particular during the bloom peak (Days 2-3), with maximum concentrations reaching $4.5 \mu \mathrm{g} \mathrm{chl} \mathrm{a} \mathrm{l}^{-1}$ compared to

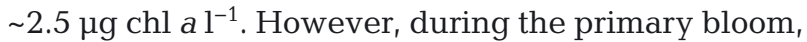
maximum concentrations of chl a and FCM-derived biomass (i.e. cell numbers) diverged temporally by $2 \mathrm{~d}$, and the secondary phytoplankton bloom ap- 

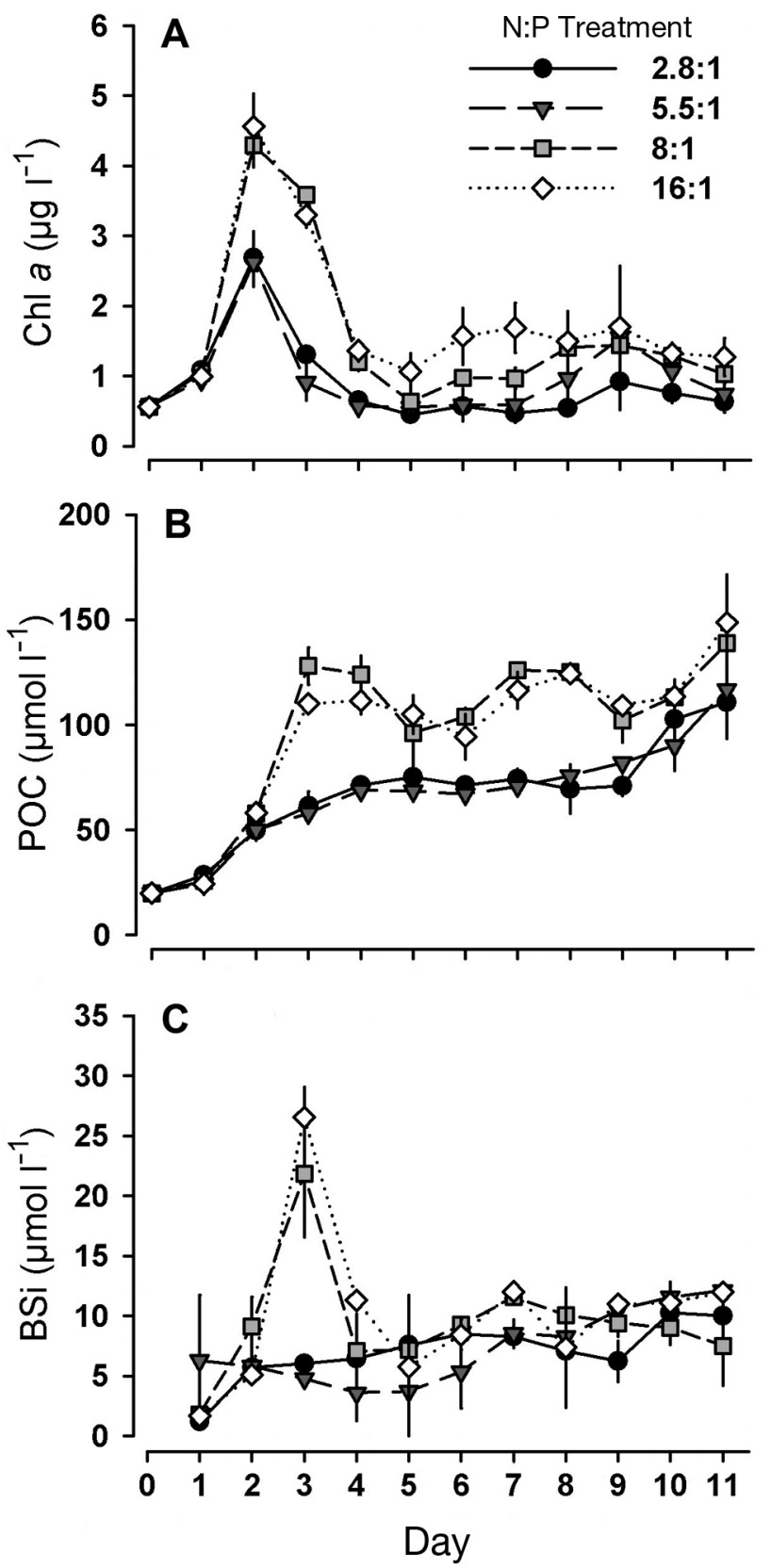

Fig. 3. Temporal development of (A) chl $a_{\text {, }}$ (B) particulate organic carbon (POC) and (C) biogenic silica (BSi) within the $4 \mathrm{~N}$ :P treatments (see 'Materials and methods' for treatment details). Values are treatment means and vertical error bars denote the standard error of replicates within each $\mathrm{N}: \mathrm{P}$ treatment

peared considerably more pronounced in the data obtained from FCM compared to chl a.

Like the photoautotrophic proxies, total POC development was driven by $\mathrm{N}$ availability (Fig. 3B). A primary (Days 3-4) and secondary bloom peak (Days 7-8) with concentrations of about $120 \mu \mathrm{mol} \mathrm{POC} \mathrm{l}^{-1}$ appeared in the high-N treatments, while POC did not exceed $70 \mu \mathrm{mol} \mathrm{l}^{-1}$ until Day 10 in the low-N treatments. On the last sampling day, POC increased to maximum concentrations of $\sim 140 \mu \mathrm{mol} \mathrm{l}^{-1}$ (high N) and $\sim 110 \mu \mathrm{mol}^{-1}$ (low N).

The uptake of $\mathrm{Si}(\mathrm{OH})_{4}$ was reflected in the accumulation of BSi in the individual treatments, as maximum values of $\sim 24 \mu \mathrm{mol} \mathrm{BSi} l^{-1}\left(\sim 7 \mu \mathrm{mol} \mathrm{BSi} l^{-1}\right.$ standard deviation) occurred in the high-N mesocosms (Fig. 3C). In contrast, BSi accumulated only gradually in the low-N treatments, hardly surpassing concentrations of $10 \mu \mathrm{mol} \mathrm{l}^{-1}$ throughout the experiment. Thus, production of BSi was significantly affected by the initial N supply, whereas initial P enrichment did not have any effect (Table 2).

Fucoxanthin, chl $\mathrm{C}_{1+2}$ and diadinoxanthin represented the most dominant phytopigments in terms of concentrations (Fig. 4). Together with diatoxanthin and $\beta$-carotene, they function as marker pigments for diatom abundance. These 5 pigments displayed a similar pattern of distribution in the individual treatments, significantly controlled by $\mathrm{N}$ supply and only differing in their concentration levels (Table 2). Pigment concentrations were high in the high- $\mathrm{N}$ treatments and comparatively low in the low-N treatments. This effect was most pronounced during the exponential phase (Days 2-3), differing in concentration by a factor of 2 .

Production of the xanthophylls aphanizophyll and myxoxanthophyll, both occurring only in cyanobacteria, was affected by $\mathrm{N}$ supply (Fig. 5A,B, Table 2). They hardly accumulated in the low- $\mathrm{N}$ treatments (e.g. $<0.05 \mu \mathrm{g} \mathrm{l}^{-1}$ aphanizophyll), whereas concentrations reached maximum levels between Days 4 and 6 in the high-N treatments (e.g. $~ 0.17 \mu \mathrm{g} \mathrm{l}^{-1}$ aphanizophyll). Despite this clearly visible result, $\mathrm{N}$ supply did not have a statistically significant effect on aphanizophyll over the entire experiment (Table 2). This is due to the general absence of aphanizophyll in all treatments before and also partly after the pigment peak, which occurred between Days 4 and 7 .

Chl $c_{3}$ and the carotenoid 19'-hexanoyloxyfucoxanthin are mainly synthesized by haptophytes. Only 19'-hexanoyloxyfucoxanthin responded to N supply according to statistical testing (Table 2). However, $\mathrm{chl} C_{3}$ accumulated somewhat more strongly in the high-N mesocosms from Day 6 onwards (Fig. 5C,D).

$\mathrm{Chl} b$ and the carotenoid violaxanthin are marker pigments for chlorophytes. We found no significant effect of nutrient supply on either pigment (Table 2), although maximum concentrations on Days 2 and 3 were larger in the high-N mesocosms (Fig. 5E,F).

Concentration of the picocyanobacterial marker zeaxanthin was highest in the 16:1 treatment 

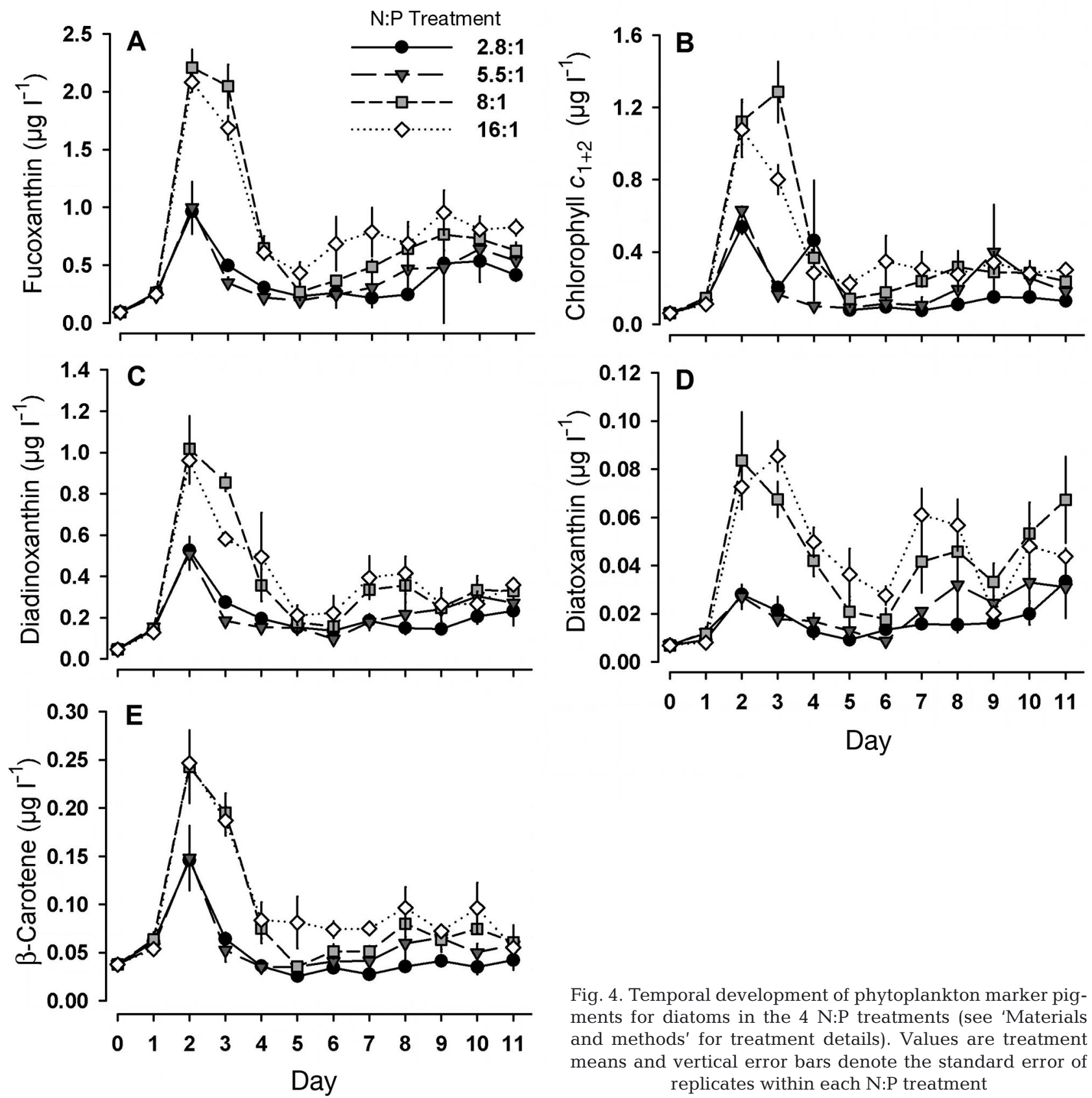

Fig. 4. Temporal development of phytoplankton marker pigments for diatoms in the $4 \mathrm{~N}$ :P treatments (see 'Materials and methods' for treatment details). Values are treatment means and vertical error bars denote the standard error of replicates within each N:P treatment

(Fig. 6A); however, the variability among replicates within this treatment was rather large throughout the experiment due to the accumulation of higher concentrations in 1 of the 3 replicate mesocosms. Statistical testing revealed a significant effect of $\mathrm{N}$ as well as of $\mathrm{P}$ supply on this pigment.

In contrast to many other carotenoids, peridinin is exclusively produced by dinoflagellates, thus representing an unambiguous indicator for the abundance of this phytoplankton group. The concentration of peridinin in the different treatments was significantly influenced by $\mathrm{N}$ supply (Fig. 6B, Table 2).

Alloxanthin is a diagnostic pigment for the abundance of cryptophytes. Statistical analysis did not reveal a significant effect of nutrient supply on alloxanthin development over the total experimental duration (Table 2). However, alloxanthin levels were higher in the high- $\mathrm{N}$ than in the low- $\mathrm{N}$ treatments during the peak phase from Days 2 to 4 (Fig. 6C).

Development of 19'-butanoyloxyfucoxanthin, predominantly produced by chrysophytes, was not significant between the treatments, and concentrations were extremely low throughout the experiment (Fig. 6D, Table 2). 

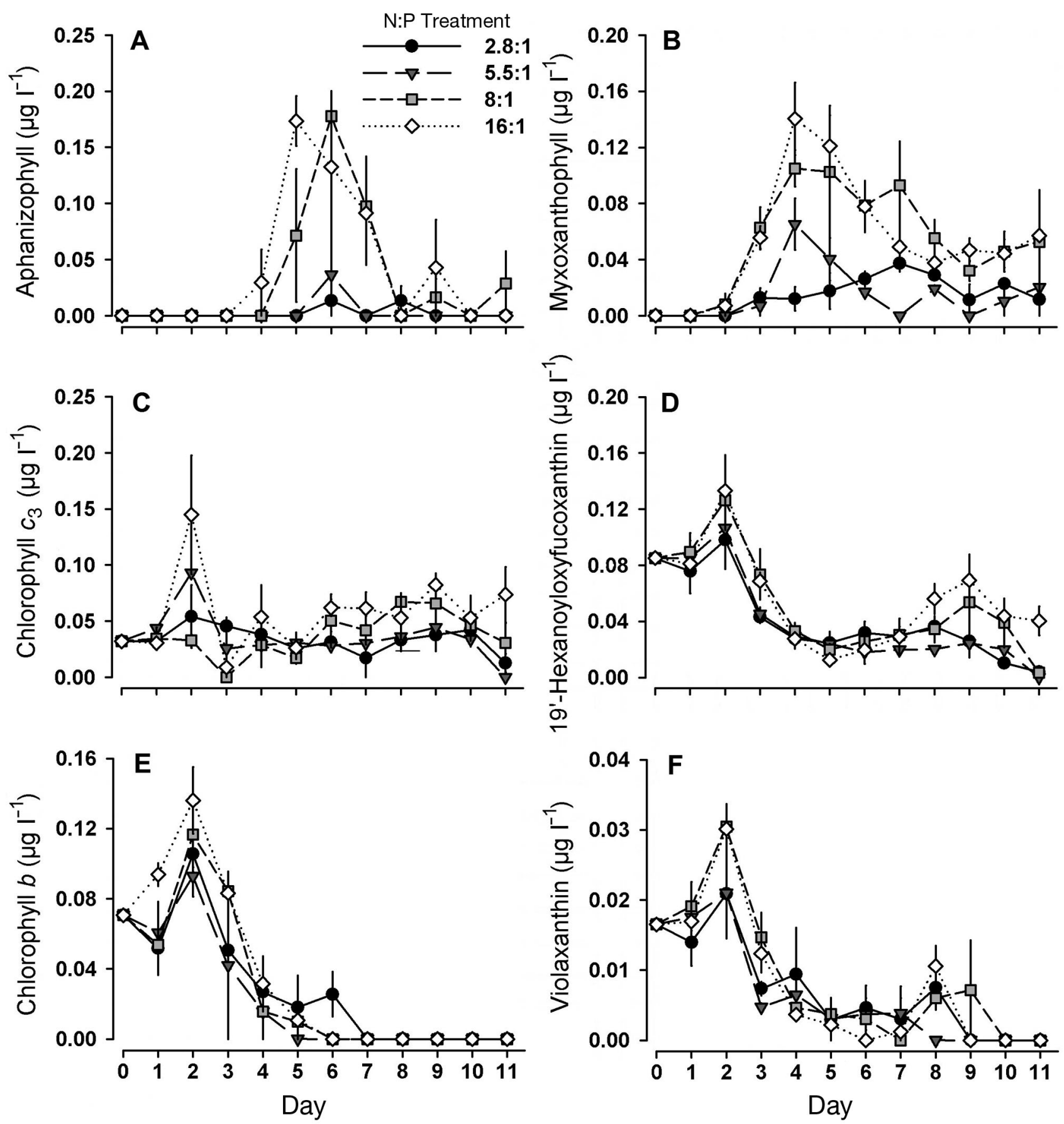

Fig. 5. Temporal development of phytoplankton marker pigments for $(A, B) N_{2}$-fixing cyanobacteria, $(C, D)$ haptophytes and (E,F) chlorophytes in the $4 \mathrm{~N}: \mathrm{P}$ treatments (see 'Materials and methods' for treatment details). Values are treatment means and vertical error bars denote the standard error of replicates within each N:P treatment

Quantification of cluster-specific nifH gene abundances in the mesocosms revealed high abundance of filamentous Trichodesmium (Fig. 7), along with scarce abundance of unicellular Crocosphaera-like species, Gammaproteobacteria, Group A and diatom -diazotroph associations (DDAs; data not shown). Trichodesmium-specific nifH gene copies were present in the mesocosms from the start of the experi- ment, but copy numbers showed an abrupt rise from Day 7 onwards. The number of nifH gene copies did not respond to $\mathrm{N}$ or $\mathrm{P}$ supply (Table 2). The abundance of nifH genes affiliated to Trichodesmium sp. and the distribution of the cyanobacterial marker pigments myxoxanthophyll and aphanizophyll (Fig. 5A,B) showed no agreement over time or between treatments. 

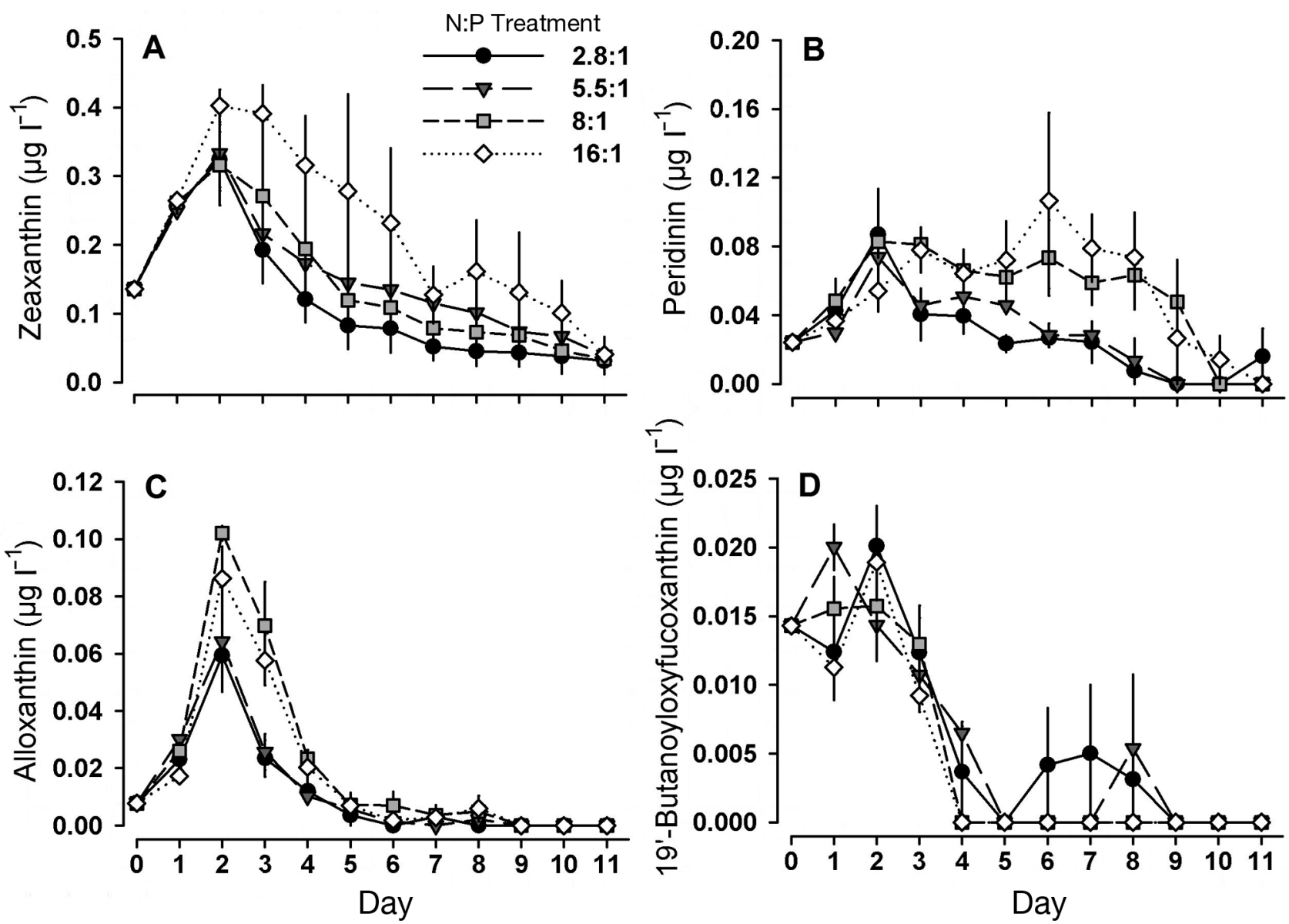

Fig. 6. Temporal development of phytoplankton marker pigments for (A) picocyanobacteria (e.g. Synechococcus), (B) dinoflagellates, (C) cryptophytes and (D) chrysophytes in the $4 \mathrm{~N}: \mathrm{P}$ treatments (see 'Materials and methods' for treatment details). Values are treatment means and vertical error bars denote the standard error of replicates within each N:P treatment

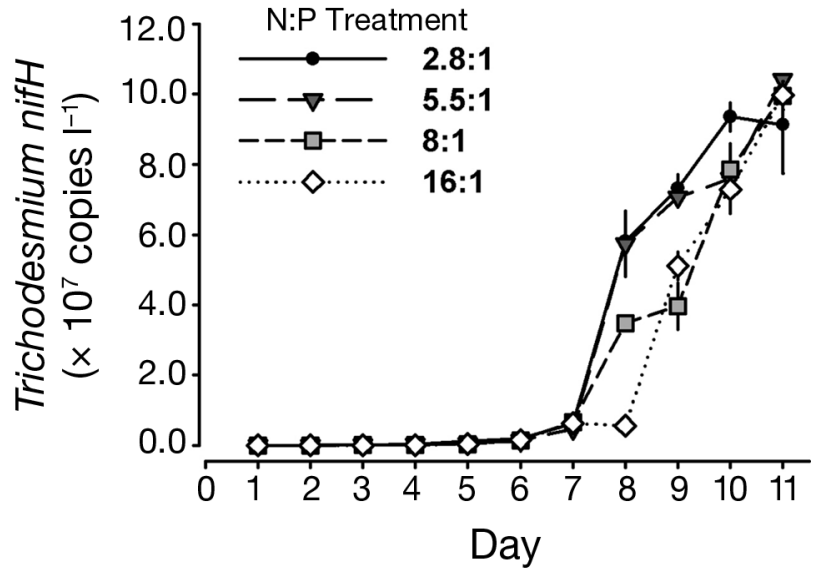

Fig. 7. Temporal development of Trichodesmium nifH gene copy abundance within the $4 \mathrm{~N}: \mathrm{P}$ treatments on a log-scale (see 'Materials and methods' for treatment details). Values are treatment means and vertical error bars denote the standard error of replicates within each $\mathrm{N}: \mathrm{P}$ treatment

\section{DISCUSSION}

\section{N supply controls phytoplankton growth}

Phytoplankton biomass (as observed by cell counts and pigments) as well as total particulate matter was significantly affected by the level of $\mathrm{N}$ supply but not by the N:P supply ratio. Addition of combined high amounts of $\mathrm{N}$ and $\mathrm{P}$ did not provoke a further increase in algal biomass compared to the high $\mathrm{N}$ enrichment alone. Hence, growth of bulk phytoplankton was solely controlled by the availability of $\mathrm{N}$, a response that has been previously observed in association with coastal upwelling communities (Thomas et al. 1974, Hauss et al. 2012). Yet, the majority of nutrient enrichment experiments performed in subtropical and tropical oceanic environments reported an apparent synergistic limitation by the major nutrients $\mathrm{N}$ and $\mathrm{P}$ on primary production (Graziano et al. 1996, Davey et al. 2008, Moore et al. 
2008, Tang et al. 2009). Such an additive control of growth by $\mathrm{N}$ and $\mathrm{P}$ is rather common in oligotrophic lakes (e.g. White \& Payne 1977, Elser et al. 1990). Under conditions of low nutrient availability, neutralization of the proximate nutrient limitation by enrichment of this nutrient was reported to quickly cause limitation of the phytoplankton assemblage by the 'secondary' limiting nutrient. This succession of nutrient limitation may also apply to the abovementioned marine enrichment experiments, as they were likewise performed in nutrient-impoverished waters of the oligotrophic ocean gyres. However, results from Droop (1974) and Rhee (1978) confirmed Liebig's law of the minimum, which states that growth is solely controlled by the ultimate limiting nutrient. Rhee (1978) explained the additive effect of combined $\mathrm{N}$ and $\mathrm{P}$ addition with a competitive exclusion and coexistence of populations either limited by $\mathrm{N}$ or by $\mathrm{P}$. Combined enrichment of $\mathrm{N}$ and $\mathrm{P}$ would stimulate growth of the $\mathrm{N}$ - and the P-limited species, resulting in a higher biomass yield than single addition of $\mathrm{N}$ or P. Hence, in addition to N-limited species, photoautotrophic communities in the oligotrophic ocean are presumably also composed of P-limited species, which jointly define the response of the total algal assemblage. However, in our study, phytoplankton biomass was highly dominated by diatoms, and analysis of photoautotrophic marker pigments did not show any phytoplankton group limited by $\mathrm{P}$ concentration (see Table 2). Accordingly, total phytoplankton showed a pattern of only N-limitation. The strong dominance of $\mathrm{N}$-controlled blooming phytoplankton in coastal upwelling areas seems to exclude the apparent additive growth effect of combined $\mathrm{N}$ and $\mathrm{P}$ enrichment observed in oligotrophic regions.

\section{Diatom-dominated phytoplankton community}

Comparison of the distribution of chl $a_{1}$ BSi and diatom-associated pigments demonstrates a strong dominance of the microalgal assemblage in all treatments by diatoms, in agreement with the response of phytoplankton in a similar enrichment experiment conducted in the Peruvian upwelling (Hauss et al. 2012). Artificial nutrient addition, comparable to an episodic upwelling event, triggered fast nutrient drawdown and exponential growth of diatoms. The metabolism of this phytoplankton group is known to react promptly to sudden pulses of nutrient input with extremely high rates of nutrient uptake and cell division (Fawcett \& Ward 2011). This quick metabolic response may be the crucial advantage of diatoms to outcompete other phytoplankton groups in high nutrient regimes such as upwelling areas. Especially picoplanktonic species are less competitive under nutrient saturation. Small cells are highly beneficial when nutrients are depleted due to their high surface area to volume ratio, which reduces limitation of molecular diffusion during nutrient uptake (Chisholm 1992). But picoplanktic cells might have a disadvantage in coexistence with large blooming species in eutrophic environments (Wilkerson et al. 2000, Wetz $\&$ Wheeler 2003). There is evidence that abundance of small cells is highly controlled by microzooplankton grazing. A higher grazing pressure has been detected for picoplankton compared to nano- and microphytoplankton, particularly under nutrient-rich conditions (e.g. Calbet 2001, 2008). Larger cells like diatoms can even escape top-down control by mesozooplankton grazing when $\mathrm{N}$ is available in high concentrations, as copepods are constrained by their longer development cycle (Goericke 2002).

Blooming and dominance of diatoms is certainly further influenced by the availability of $\mathrm{Si}(\mathrm{OH})_{4}$ and Fe. $\mathrm{Si}(\mathrm{OH})_{4}$ is vital for building their silica-containing cell walls. In addition, particularly coastal diatoms seem to have high Fe requirements (Sunda \& Huntsman 1995, Bruland et al. 2001), and their growth has been reported to be limited by Fe supply when $\mathrm{N}$ concentrations are high (Hutchins \& Bruland 1998, Hare et al. 2005). $\mathrm{Si}(\mathrm{OH})_{4}$ and Fe were both initially provided to the phytoplankton community in adequate concentrations, to prevent limitation by nutrients other than $\mathrm{N}$ and $\mathrm{P}$.

\section{Diatom-diazotroph succession}

The single-pulse nutrient addition experiment in this study simulates an upwelling event as it may occur on the West African coast. Following the characteristic succession of functional groups in such experiments can therefore help to explain their spatial distribution patterns along the water column and on the shelf-slope-open ocean transect which is characteristic of eastern boundary current systems. Observations by Margalef (1978) and model predictions by Hood et al. (2004) suggest that the succession sequence diatoms-cyanobacteria-flagellates might be characteristic of the ETNA. Traditionally, large-scale $\mathrm{N}$ input by $\mathrm{N}_{2}$ fixation has been principally linked to the central and western part of the North Atlantic. This common view is based upon the dominance of Trichodesmium and the high N:P export ratio in these regions (Capone et al. 2005). 
More recently, substantial $\mathrm{N}$ inputs by $\mathrm{N}_{2}$ fixation have been detected in the ETNA (Großkopf et al. 2012, Hauss et al. 2013, Sandel et al. 2015). Besides the well known Trichodesmium, other cyanobacteria may also contribute to microbial $\mathrm{N}_{2}$ fixation, as the role of unicellular cyanobacteria as well as DDAs in the waters of the tropical North Atlantic has been increasingly discussed (Montoya et al. 2007, Langlois et al. 2008, Foster et al. 2009).

Episodic pulses of nutrient-rich upwelled water facilitate blooms of large primary producers, which induce rapid drawdown of the supplied $\mathrm{N}$ in the surface layer. $\mathrm{N}$ depletion following upwelling events may create a niche for cyanobacterial diazotrophs. Subramaniam et al. (2013) and Sandel et al. (2015) found that $\mathrm{N}_{2}$ fixation in the equatorial upwelling system is surprisingly high, contradicting the traditional view that $\mathrm{N}_{2}$ fixation is suppressed under high $\mathrm{N}$ availability. In this study, exhaustion of initially supplied $\mathrm{N}$ on Day 3 (Fig. 1A) terminated a diatomdominated bloom (see Figs. $3 \& 4$ ), thereby providing favourable conditions for the onset of diazotrophic development. Temporal distribution of the cyanobacterial marker pigments myxoxanthophyll and aphanizophyll was inversely correlated with the development of the diatom bloom, as maximum pigment concentrations occurred between Days 4 and 6 (Fig. 5A). The highest increase in the abundance of the Trichodesmium-specific nifH gene, the functional gene expressing the $\mathrm{N}_{2}$ fixation catalyzing enzyme nitrogenase-reductase, also occurred after termination of the diatom bloom from Day 7 onwards. Declining diatom abundance seems to create conditions favouring extensive growth of diazotrophic cyanobacteria. Despite the common assumption that $\mathrm{N}_{2}$ fixing cyanobacteria are in general unable to assimilate DIN, Trichodesmium is able to grow on $\mathrm{NO}_{3}^{-}$ (Holl \& Montoya 2005). However, coexistence of diatoms and diazotrophs under nutrient saturation is eliminated by the fact that cyanobacteria cannot compete with diatoms for the available $\mathrm{P}$ (Tilman 1982). Based on the high abundance of the Trichodesmium-specific nifH gene (see Fig. 7) in combination with only scarce copy numbers of nifH genes from unicellular cyanobacteria and DDAs (data not shown), we assume that aphanizophyll and myxoxanthophyll are primarily Trichodesmium-derived. Consequently, Trichodesmium developed under nutrient depletion subsequent to the diatom-dominated primary phytoplankton bloom, which supports the hypothesis (see Margalef 1978, Hood et al. 2004) that $\mathrm{N}_{2}$-fixers grow in succession to diatoms in the upwelling area on the West African continental shelf.
Many observations support the notion that low N:P conditions stimulate growth of $\mathrm{N}_{2}$-fixers (e.g. Niemi 1979, Vrede et al. 2009). But neither increased production of cyanobacterial marker pigments in the high-N treatments of the present study, a response that has already been observed in the mesocosm study by Hauss et al. (2012), nor similar copy numbers of the Trichodesmium-specific nifH gene across all treatments (Fig. 7, Table 2) indicate a stimulation of diazotrophic cyanobacteria by low N:P supply ratios. This is also in agreement with a more recent mesocosm study from the ETNA region (Meyer et al. 2015). In that study, $\mathrm{N}_{2}$ fixation was found to be independent of $\mathrm{N}$ :P ratios, but a stimulation of $\mathrm{N}_{2}$ fixation by dissolved organic P had been described for DDAs when DIP pools were depleted. In our study, production of myxoxanthophyll and aphanizophyll was lowest in the 2.8:1 N:P treatment, which was the only treatment with residual amounts of DIP throughout the entire experiment. Likewise, excess $\mathrm{P}$ did not induce an increase in nifH gene copy numbers compared to the other treatments, implying that growth of diazotrophic algae was not limited by $\mathrm{P}$ availability. However, the discrepancy in the distribution of marker pigments and nifH gene abundance prevents us from making a definite statement about how $\mathrm{N}_{2}$ fixing cyanobacteria responded to variable nutrient supply in the experiment. Nonetheless, the similarity in the increased production of cyanobacterial marker pigments in the high-N treatments between this study and that of Hauss et al. (2012) suggests a commonality in this response, which we are not able to explain with the available dataset at this point.

Furthermore, the disagreement in development between cyanobacterial diagnostic pigments and nifH gene copies reveals that our present comprehension of microalgal indicators is rather incomplete. Owing to this inconsistency and the associated uncertainty of the cyanobacterial proxies, and simply because we did not perform rate measurements of $\mathrm{N}_{2}$ fixation, we are not able to evaluate the input of bioavailable $\mathrm{N}$ via $\mathrm{N}_{2}$ fixation into the microbial food web within the various mesocosms. Given that a secondary weaker diatom bloom developed after Day 7 , showing the same pattern of $\mathrm{N}$ control, we suspect that an effective remineralization of nutrients must have occurred between the first and second bloom.

\section{Ecological implications}

Results from this simulated upwelling experiment show that primary production in the ETNA is ulti- 
mately N-limited and that phytoplankton occur in a successional sequence as proposed by the model of Hood et al. (2004). Following upwelling pulses and drawdown of nutrients by bloom-forming species such as diatoms, coastal shelf areas offer favourable growth conditions for $\mathrm{N}_{2}$-fixers, provided that the vertical supply of nutrients occurs only episodically. Water masses with upwelling characteristics, potentially populated by diazotroph producers, can be transported hundreds of miles offshore by westwardpropagating eddies. Since regions with high vertical diffusive $\mathrm{N}$ flux to the surface are commonly not considered as potential habitats for diazotrophic phytoplankton, total input of $\mathrm{N}$ via $\mathrm{N}_{2}$-fixation may have been underestimated in the eastern tropical Atlantic Ocean. So far, results indicate an absence of largescale $\mathrm{N}$ loss via anammox or denitrification in the water column off northwestern Africa (Ryabenko et al. 2011), because relatively high minimum $\mathrm{O}_{2}$ con-

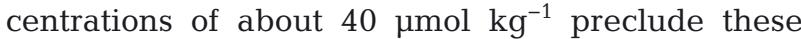
microbial pathways. There is, however, scope for substantial change, as the ETNA has been identified as the region with the largest potential for expansion of low-oxygen intermediate waters based on models (Matear \& Hirst 2003) and time-series analysis (Stramma et al. 2008). As a consequence, N loss processes may gradually establish in the deoxygenating waters of the tropical eastern Atlantic. The resulting expansion of the $\mathrm{N}$ deficit may constrain the development of N-limited diatom blooms, which account for a large part of primary production in this area. The ecological importance of $\mathrm{N}_{2}$-fixing cyanobacteria prospering subsequent to $\mathrm{N}$-scavenging diatoms in the course of upwelling processes might thus increase in the biogeochemical system projected for the ETNA under climate change scenarios.

Acknowledgements. We thank Kerstin Nachtigall, Martina Lohmann and the captain, crew and chief scientist of RV 'Meteor' for their support during the M83-1 cruise. This work is a contribution of the Sonderforschungsbereich 754 'Climate-Biogeochemistry Interactions in the Tropical Ocean' (www.sfb754.de), which is supported by the German Research Foundation (DFG).

\section{LITERATURE CITED}

Arrigo KR (2005) Marine microorganisms and global nutrient cycles. Nature 437:349-355

Barlow RG, Cummings DG, Gibb SW (1997) Improved resolution of mono-and divinyl chlorophylls $a$ and $b$ and zeaxanthin and lutein in phytoplankton extracts using reverse phase C-8 HPLC. Mar Ecol Prog Ser 161:303-307

Bertilsson S, Berglund O, Karl DM, Chisholm SW (2003) Elemental composition of marine Prochlorococcus and
Synechococcus: implications for the ecological stoichiometry of the sea. Limnol Oceanogr 48:1721-1731

Bruland KW, Rue EL, Smith GJ (2001) Iron and macronutrients in California coastal upwelling regimes: implications for diatom blooms. Limnol Oceanogr 46:1661-1674

Calbet A (2001) Mesozooplankton grazing effect on primary production: a global comparative analysis in marine ecosystems. Limnol Oceanogr 46:1824-1830

Calbet A (2008) The trophic roles of microzooplankton in marine ecosystems. ICES J Mar Sci 65:325-331

Capone DG, Zehr JP, Paerl HW, Bergman B, Carpenter EJ (1997) Trichodesmium, a globally significant marine cyanobacterium. Science 276:1221-1229

Capone DG, Burns JA, Montoya JP, Subramaniam A and others (2005) Nitrogen fixation by Trichodesmium spp.: an important source of new nitrogen to the tropical and subtropical North Atlantic Ocean. Global Biogeochem Cycles 19:GB2024, doi:1029/2004GB002331

Chisholm SW (1992) Phytoplankton size. In: Falkowski WG, Woodhead AD (eds) Primary productivity and biogeochemical cycles in the sea. Plenum Press, New York, NY, p 213-273

> Davey M, Tarran GA, Mills MM, Ridame C, Geider RJ, LaRoche J (2008) Nutrient limitation of picophytoplankton photosynthesis and growth in the tropical North Atlantic. Limnol Oceanogr 53:1722-1733

> Droop MR (1974) The nutrient status of algal cells in continuous culture. J Mar Biol Assoc UK 54:825-855

Elser JJ, Marzolf ER, Goldman CR (1990) Phosphorus and nitrogen limitation of phytoplankton growth in the freshwaters of North America: a review and critique of experimental enrichments. Can J Fish Aquat Sci 47: 1468-1477

Falcón LI, Cipriano F, Chistoserdov AY, Carpenter EJ (2002) Diversity of diazotrophic unicellular cyanobacteria in the tropical North Atlantic Ocean. Appl Environ Microbiol 68:5760-5764

> Falcón LI, Pluvinage S, Carpenter EJ (2005) Growth kinetics of marine unicellular $\mathrm{N}_{2}$-fixing cyanobacterial isolates in continuous culture in relation to phosphorus and temperature. Mar Ecol Prog Ser 285:3-9

Fanning KA (1992) Nutrient provinces in the sea: concentration ratios, reaction-rate ratios, and ideal covariation. J Geophys Res 97:5693-5712

> Fawcett SE, Ward BB (2011) Phytoplankton succession and nitrogen utilization during the development of an upwelling bloom. Mar Ecol Prog Ser 428:13-31

$>$ Foster RA, Subramaniam A, Mahaffey C, Carpenter EJ, Capone DG, Zehr JP (2007) Influence of the Amazon River plume on distributions of free-living and symbiotic cyanobacteria in the western tropical North Atlantic Ocean. Limnol Oceanogr 52:517-532

$>$ Foster RA, Subramaniam A, Zehr JP (2009) Distribution and activity of diazotrophs in the Eastern Equatorial Atlantic. Environ Microbiol 11:741-750

- Franz J, Krahmann G, Lavik G, Grasse P, Dittmar P, Riebesell U (2012a) Dynamics and stoichiometry of nutrients and phytoplankton in waters influenced by the oxygen minimum zone in the tropical eastern Pacific. Deep-Sea Res I 62:20-31

> Franz JMS, Hauss H, Sommer U, Dittmar T, Riebesell U (2012b) Production, partitioning and stoichiometry of organic matter under variable nutrient supply during mesocosm experiments in the tropical Pacific and Atlantic Ocean. Biogeosciences 9:4629-4643 
Gao Y, Kaufman YJ, Tanré D, Kolber D, Falkowski PG (2001) Seasonal distributions of aeolian iron fluxes to the global ocean. Geophys Res Lett 28:29-32

Goericke R (2002) Top-down control of phytoplankton biomass and community structure in the monsoonal Arabian Sea. Limnol Oceanogr 47:1307-1323

Graziano LM, Geider RJ, Li WKW, Olaizola M (1996) Nitrogen limitation of North Atlantic phytoplankton: analysis of physiological condition in nutrient enrichment experiments. Aquat Microb Ecol 11:53-64

Großkopf T, Mohr W, Baustian T, Schunck H and others (2012) Doubling of marine dinitrogen-fixation rates based on direct measurements. Nature 488:361-364

Hansen HP, Koroleff F (1999) Determination of nutrients. In: Grasshoff K, Kremling K, Ehrhardt M (eds) Methods of seawater analysis. Wiley-VCH Verlag, Weinheim, p 159-228

> Hare CE, DiTullio GR, Trick CG, Wilhelm SW, Bruland KW, Rue EL, Hutchins DA (2005) Phytoplankton community structure changes following simulated upwelled iron inputs in the Peru upwelling region. Aquat Microb Ecol 38:269-282

> Hauss H, Franz JMS, Sommer U (2012) Changes in N:P stoichiometry influence taxonomic composition and nutritional quality of phytoplankton in the Peruvian upwelling. J Sea Res 73:74-85

- Hauss HM, Franz J, Hansen T, Struck U, Sommer U (2013) Relative inputs of upwelled and atmospheric nitrogen to the eastern tropical North Atlantic food web: spatial distribution of $\delta^{15} \mathrm{~N}$ in mesozooplankton and relation to dissolved nutrient dynamics. Deep-Sea Res I 75:135-145

> Holl CM, Montoya JP (2005) Interactions between nitrate uptake and nitrogen fixation in continuous cultures of the marine diazotroph Trichodesmium (Cyanobacteria). J Phycol 41:1178-1183

> Holmes RM, Aminot A, Kérouel R, Hooker BA, Peterson BJ (1999) A simple and precise method for measuring ammonium in marine and freshwater ecosystems. Can J Fish Aquat Sci 56:1801-1808

Hood RR, Coles VJ, Capone DG (2004) Modeling the distribution of Trichodesmium and nitrogen fixation in the Atlantic Ocean. J Geophys Res 109:C06006, doi:10.1029/ 2002JC001753

Hutchins DA, Bruland KW (1998) Iron-limited diatom growth and $\mathrm{Si}: \mathrm{N}$ uptake ratios in a coastal upwelling regime. Nature 393:561-564

- Jaeschke A, Abbas B, Zabel M, Hopmans EC, Schouten S, Sinninghe Damsté JS (2010) Molecular evidence for anaerobic ammonium-oxidizing (anammox) bacteria in continental shelf and slope sediments off northwest Africa. Limnol Oceanogr 55:365-376

Karstensen J, Stramma L, Visbeck M (2008) Oxygen minimum zones in the eastern tropical Atlantic and Pacific Oceans. Prog Oceanogr 77:331-350

Karstensen J, Fiedler B, Schütte F, Brandt P and others (2015) Open ocean dead-zone in the tropical North Atlantic Ocean. Biogeosciences 12:2597-2605

Langlois RJ, Hümmer D, LaRoche J (2008) Abundances and distributions of the dominant nifH phylotypes in the Northern Atlantic Ocean. Appl Environ Microbiol 74: 1922-1931

Margalef R (1978) Phytoplankton communities in upwelling areas. The example of Northwest Africa. Oecol Aquat 3: 97-132

Matear RJ, Hirst AC (2003) Long-term changes in dissolved oxygen concentrations in the ocean caused by protracted global warming. Global Biogeochem Cycles 17:1125, doi: 10.1029/2002GB001997

Menden-Deuer S, Lessard EJ (2000) Carbon to volume relationships for dinoflagellates, diatoms, and other protist plankton. Limnol Oceanogr 45:569-579

> Meyer J, Löscher CR, Neulinger SC, Reichel A and others (2015) Changing nutrient stoichiometry affects phytoplankton production, DOP build up and dinitrogen fixation - a mesocosm experiment in the eastern tropical North Atlantic. Biogeosci Discuss 12:9991-10029

Mills MM, Arrigo KR (2010) Magnitude of oceanic nitrogen fixation influenced by the nutrient uptake ratio of phytoplankton. Nat Geosci 3:412-416

Mills MM, Ridame C, Davey M, LaRoche J, Geider RJ (2004) Iron and phosphorus co-limit nitrogen fixation in the eastern tropical North Atlantic. Nature 429:292-294

Montoya JP, Voss M, Capone DG (2007) Spatial variation in $\mathrm{N}_{2}$-fixation rate and diazotroph activity in the Tropical Atlantic. Biogeosciences 4:369-376

Moore CM, Mills MM, Langlois R, Milne A, Achtberg EP, LaRoche J, Geider RJ (2008) Relative influence of nitrogen and phosphorus availability on phytoplankton physiology and productivity in the oligotrophic sub-tropical North Atlantic Ocean. Limnol Oceanogr 53:291-305

Niemi A (1979) Blue-green algal blooms and N:P ratio in the Baltic Sea. Acta Bot Fenn 110:57-61

> Nixon SW, Ammerman JW, Atkinson LP, Berounsky VM and others (1996) The fate of nitrogen and phosphorus at the land-sea margin of the North Atlantic Ocean. Biogeochemistry 35:141-180

Quigg A, Finkel ZV, Irwin AJ, Rosenthal Y and others (2003) The evolutionary inheritance of elemental stoichiometry in marine phytoplankton. Nature 425:291-294

$>$ Rhee GY (1978) Effects of N:P atomic ratios and nitrate limitation on algal growth, cell composition, and nitrate uptake. Limnol Oceanogr 23:10-25

> Riegman R, Noordeloos AAM, Cadée GC (1992) Phaeocystis blooms and eutrophication of the continental coastal zones of the North Sea. Mar Biol 112:479-484

Ryabenko E, Kock A, Bange HW, Altabet MA, Wallace DWR (2011) Contrasting biogeochemistry of nitrogen in the Atlantic and Pacific oxygen minimum zones. Biogeosci Discuss 8:8001-8039

Ryther JH, Dunstan WM (1971) Nitrogen, phosphorus, and eutrophication in the coastal marine environment. Science 171:1008-1013

Sandel V, Kiko R, Brandt P, Dengler M and others (2015) Nitrogen fuelling of the pelagic food web of the tropical Atlantic. PLoS ONE 10:e0131258

> Stramma L, Johnson GC, Sprintall J, Mohrholz V (2008) Expanding oxygen-minimum zones in the tropical oceans. Science 320:655-658

Subramaniam A, Mahaffey C, Johns W, Mahowald N (2013) Equatorial upwelling enhances nitrogen fixation in the Atlantic Ocean. Geophys Res Lett 40:1766-1771

Sunda WG, Huntsman SA (1995) Iron uptake and growth limitation in oceanic and coastal phytoplankton. Mar Chem 50:198-206

Talbot RW, Harriss RC, Browell EV, Gregory GL, Sebacher DI, Beck SM (1986) Distribution and geochemistry of aerosols in the tropical North Atlantic troposphere: relationship to Saharan dust. J Geophys Res 91: 5173-5182

Tang S, Jiang L, Wu ZJ (2009) Adding nitrate and phosphate 
separately or together in the Central Indian Ocean: a nutrient enrichment experiment. Ocean Sci Discuss 6: 2649-2666

Thomas WH, Seibert DLR, Dodson AN (1974) Phytoplankton enrichment experiments and bioassays in natural coastal sea water and in sewage outfall receiving waters off Southern California. Estuar Coast Mar Sci 2:191-206

Tilman D (1982) Resource competition and community structure. Princeton University Press, Princeton, NJ

Trimmer M, Nicholls JC (2009) Production of nitrogen gas via anammox and denitrification in intact sediment cores along a continental to slope transect in the North Atlantic. Limnol Oceanogr 54:577-589

Tyrrell T, Marañón E, Poulton AJ, Bowie AR, Harbour DS, Woodward EMS (2003) Large-scale latitudinal distribution of Trichodesmium spp. in the Atlantic Ocean. J Plankton Res 25:405-416

Voss M, Croot P, Lochte K, Mills M, Peeken I (2004) Patterns of nitrogen fixation along $10^{\circ} \mathrm{N}$ in the tropical Atlantic. Geophys Res Lett 31:L23S09, doi:10.1029/2004GL020127

Vrede T, Ballantyne A, Mille Lindblom C, Algesten G, Gudasz C, Lindahl S, Brunberg AK (2009) Effects of N:P loading ratios on phytoplankton community composition,

Editorial responsibility: Graham Savidge,

Portaferry, UK primary production and $\mathrm{N}$ fixation in a eutrophic lake. Freshw Biol 54:331-344

- West JA, McBride DL (1999) Long-term and diurnal carpospore discharge patterns in the Ceramiaceae, Rhodomelaceae and Delesseriaceae (Rhodophyta). Hydrobiologia 398/399:101-113

> Wetz MS, Wheeler PA (2003) Production and partitioning of organic matter during simulated phytoplankton blooms. Limnol Oceanogr 48:1808-1817

White E, Payne GW (1977) Chlorophyll production, in response to nutrient additions, by the algae in Lake Taupo water. NZ J Mar Freshw Res 11:501-507

Wilkerson FP, Dugdale RC, Kudela RM, Chavez FP (2000) Biomass and productivity in Monterey Bay, California: contribution of the large phytoplankton. Deep-Sea Res II 47:1003-1022

> Wu J, Sunda W, Boyle EA, Karl DM (2000) Phosphate depletion in the western North Atlantic Ocean. Science 289: 759-762

Zani S, Mellon MT, Collier JL, Zehr JP (2000) Expression of nifH genes in natural microbial assemblages in Lake George, New York, detected by reverse transcriptase PCR. Appl Environ Microbiol 66:3119-3124

Submitted: September 24, 2015; Accepted: January 1, 2016 Proofs received from author(s): February 5, 2016 